\title{
Penilaian Kinerja Widyaiswara pada Diklat Revolusi Mental di Balai Diklat Keagamaan Palembang
}

\author{
Basuki \\ Balai Diklat Keagamaan Palembang \\ prabumulihbasuki@gmail.com \\ Diterima:2 Juli 2021 | Disetujui: 12 Juli 2021 | Dipublikasikan : 15 Juli 2021
}

\begin{abstract}
Abstrak
Penelitian ini bertujuan untuk mengetahui kinerja dikjartih widyaiswara pada diklat Revolusi Mental di Balai Diklat Keagamaan Palembang. Metode yang digunakan dalam penelitian ini adalah deskriptif. Subjek penelitian ini adalah seluruh peserta diklat Revolusi Mental angkatan ke-2 yang berasal dari perwakilan kanwil Provinsi Sumatera Selatan, perwakilan kanwil Provinsi Lampung, perwakilan kanwil Provinsi Bengkulu dan perwakilan kanwil Provinsi Bangka Belitung. Hasil penilaian dikjartih terhadap widyaiswara Abu Bakar mendapatkan nilai 86,11 untuk komponen penguasaan materi dan 83,33 untuk komponen kemahiran dalam mengajar pada mata diklat konsep dasar pemimpin berkarakter. Hasil penilaian dikjartih terhadap Mardiansyah mendapatkan nilai 89,44 untuk komponen penguasaan materi dan 82,85 untuk komponen kemahiran mengajar pada mata diklat proses terbentuknya pemimpin berkarakter. Hasil penilaian kinerja widyaiswara pada diklat Revolusi Mental di Balai Diklat Keagamaan Palembang memuaskan.
\end{abstract}

Kata Kunci: Kinerja, widyaiswara, pembelajaran, Revolusi Mental

\begin{abstract}
[Penilaian Kinerja Widyaiswara pada Diklat Revolusi Mental di Balai Diklat Keagamaan Palembang]. This investigation intends to decide the presentation of the Widyaiswara Dikjartih in the Mental Revolution preparing at the Palembang Religious Education and Training Center. The technique utilized in this examination is engaging. The subjects of this investigation were all members of the second clump of Mental Revolution preparing from agents of the South Sumatra Provincial Regional Office, Lampung Province Regional Office Representatives, Bengkulu Province Regional Office Representatives and Bangka Belitung Regional Office Representatives. The consequences of the Dikjartih evaluation of Widyaiswara Abu Bakar got a score of 86.11 for the segment dominating the material and 83.33 for the part of capability in instructing the fundamental idea of character pioneer instructional classes. The consequences of the Dikjartih appraisal of Mardiansyah got a score of 89.44 for the segment of dominating the material and 82.85 for the segment of encouraging abilities in the preparation cycle for the development of character pioneers. The consequences of the evaluation of the widyaiswara's presentation at the Mental Revolution preparing at the Palembang Religious Education and Training Center are agreeable.
\end{abstract}

Keywords: execution, widyaiswara, learning, Mental Revolution

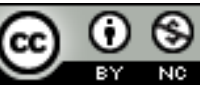

License

This work is licensed under a Creative Commons Attribution-NonCommercial 4.0 International 


\section{PENDAHULUAN}

Widyaiswara adalah jabatan fungsional yang mempunyai ruang lingkup tugas, tanggung jawab, wewenang dan hak untuk melakukan kegiatan mendidik, mengajar, melatih Pegawai Negeri Sipil (PNS) yang selanjutnya disingkat Dikjartih PNS, Evaluasi dan Pengembangan Pendidikan dan Pelatihan yang selanjutnya disingkat Diklat pada lembaga diklat pemerintah. Hal ini sesuai dengan Peraturan Menteri Pendayagunaan Aparatur Negara dan Reformasi Birokrasi (Permen PAN dan RB) nomor 22 tahun 2014 tentang Jabatan Fungsional Widyaiswara dan Angka Kreditnya.(Men PAN\&RB, 2014)

Peraturan Kepala Lembaga Administrasi Negara nomor 26 tahun 2015 tentang pedoman penilaian angka kredit jabatan fungsional widyaiswara dikatakan bahwa dikjartih adalah proses belajar mengajar dalam diklat baik secara klasikal dan/atau non klasikal. Selanjutnya dalam peraturan yang sama dikatakan bahwa kompetensi widyaiswara adalah pemilikan pengetahuan, keterampilan dan kemampuan yang dituntut oleh jabatan fungsional widyaiswara yang meliputi kompetensi pengelolaan pembelajaran, substansi, kepribadian dan sosial.

Salah satu pendidikan dan pelatihan selanjutnya disebut diklat yang diselenggarakan oleh Balai Diklat Keagamaan Palembang adalah Diklat Revolusi Mental selanjutnya disingkat Revmen. Diklat Revolusi Mental bertujuan untuk membangun manusia yang berintegritas, mau bekerja keras dan punya semangat profesionalisme, tanggung jawab, jujur, disiplin. Hal ini sesuai dengan bentuk pengejawantahan dari Inpres Nomor 12 Tahun 2016. Diklat juga sebagai langkah dan upaya nyata untuk melakukan Revolusi Mental.

Diklat Revolusi Mental memiliki sasaran tersedianya Apatur Sipil Negara (ASN) yang memiliki semangat gotong royong, memiliki nilai-nilai Revolusi Mental, berpikir positif, bersyukur, komitmen dan pantang menyerah, fokus bekerja tuntas, dapat diandalkan dan dipercaya oleh pimpinan, dan dapat mengikuti perubahan (Keputusan Kepala
LAN RI, 2019). Diklat Revolusi mental bertujuan untuk meningkatkan kompetensi Aparatur Sipil Negara (ASN) di lingkungan Kementerian Agama Republik Indonesia, agar cepat dan mampu memberikan pelayanan publik yang berkualitas.

Diklat Revolusi mental dilaksanakan di Balai Diklat Keagamaan Palembang memiliki durasi 54 jam diklat dalam enam hari. Materi mata diklat yang diajarkan terdiri atas materi mata diklat kelompok dasar, mata diklat kelompok inti dan mata diklat kelompok penunjang. Materi mata diklat kelompok inti berdurasi 36 jam diklat. Adapun materi mata diklat kelompok inti dapat dilihat pada tabel 1 .

Tabel 1 Materi mata diklat kelompok inti pada

Diklat

diklat Revolusi Mental di Balai

Keagamaan Palembang

\begin{tabular}{|c|c|c|}
\hline No & Mata Diklat & Widyaiswara \\
\hline 1 & $\begin{array}{l}\text { Konsep dasar pemimpin } \\
\text { berkarakter }\end{array}$ & Abu Bakar \\
\hline 2 & $\begin{array}{l}\text { Proses terbentuknya } \\
\text { pemimpin berkarakter }\end{array}$ & Mardiansyah \\
\hline 3 & $\begin{array}{lr}\text { Strategi membangun } \\
\text { pemimpin berkarakter } \\
\text { berbasis nilai-nilai agama }\end{array}$ & Mardiansyah \\
\hline 4 & $\begin{array}{l}\text { Internalisasi nilai-nilai } \\
\text { agama dalam membentuk } \\
\text { pemimpin berkarakter }\end{array}$ & Mardiansyah \\
\hline 5 & Personal goal setting & Mardiansyah \\
\hline
\end{tabular}

Sumber: Jadwal diklat Revolusi Mental

angkatan ke-2 tahun 2021

Dari tabel 1 dapat dibaca komposisi materi mata diklat kelompok inti dan widyaiswara yang mengampu mata diklat inti pada Diklat Revolusi Mental angkatan ke-2. Diklat ini diselenggarakan dari tanggal 5 sampai 10 April 2021 di Balai Diklat Keagamaan Palembang. Ternyata hanya ada 2 widyaiswara yang mengampu 5 materi mata diklat kelompok inti diantara Mardiansyah mengampu 4 materi mata diklat, sedangkan Abu Bakar mengampu 1 materi mata diklat inti.

Untuk mencapai tujuan dan sasaran Diklat Revolusi Mental, setiap widyaiswara dalam melaksanakan proses belajar mengajar secara klasikal harus memiliki kemampuan menguasai materi dan kemahiran mengajar. Materi diklat merupakan isi pengajaran yang dibawakan untuk mencapai suatu tujuan tertentu (sesuai yang dikehendaki kurikulum). 
Seorang widyaiswara dalam setiap kegiatan proses belajar mengajar secara klasikal harus mampu menguasai materi diklat, bahkan lebih dari itu, agar dapat mencapai hasil yang lebih baik, widyaiswara perlu menguasai bukan hanya sekedar materi tertentu yang merupakan bagian dari suatu mata diklat (subject matter) saja, tetapi menguasai yang lebih luas terhadap materi itu sendiri dapat menuntun hasil yang lebih baik (Ali, 2002). Menguasai materi secara baik adalah bagian dari kemampuan widyaiswara, biasanya merupakan tuntutan pertama dalam profesi widyaiswara. Dalam prakteknya seringkali dapat dirasakan atau diperoleh kesan tentang luas tidaknya menguasai materi dan kemahiran mengajar yang dimiliki widyaiswara. Namun itu bukan merupakan ukuran yang bersifat pasti. Sebab, masih banyak faktor yang berpengaruh terhadap proses belajar mengajar lainnya. Jadi, yang menjadi ketentuan adalah bahwa widyaiswara harus menguasai apa yang akan diajarkan dan kemahiran mengajar, agar dapat memberikan pengaruh terhadap pengalaman belajar yang berarti kepada peserta diklat.

Penilaian kinerja widyaiswara dimaksudkan untuk mengetahui bagaimanakah penilaian kinerja dikjartih widyaiswara pada diklat Revolusi Mental di Balai Diklat Keagamaan Palembang.

Penilaian kinerja widyaiswara dalam melaksanakan tugasnya, dalam arti bahwa pengetahuan dan keterampilan dapat diterima dan diserap dengan baik oleh peserta diklat jika para widyaiswara dapat meyampaikan pengetahuan dan keterampilannya dengan baik. Dengan demikian hasil belajar peserta diklat tergantung pada menguasai materi dari widyaiswara dan kemahiran mengajar widyaiswara.

Suatu proses belajar mengajar akan bisa disebut berjalan dan berhasil secara baik, manakala widyaiswara mampu mengubah peserta diklat dalam arti yang luas serta mampu menumbuhkembangkan kesadaran peserta diklat untuk belajar, sehingga pengalaman yang diperoleh peserta diklat selama terlibat proses pengajaran itu, dapat dirasakan manfaatnya secara langsung bagi perkembangan pribadinya (Rohani, 2004). Hilda Taba (dalam Nana Sudjana, 2004) menyatakan bahwa keefektifan pengajaran dipengaruhi oleh a) karakteristik guru dan siswa; b) bahan pelajaran; c) aspek lain yang berkenaan dengan situasi pelajaran.

\section{KAJIAN TEORI}

Terminologi diklat diambil dari terjemahan training. Posisi diklat, jika dilihat dari ilmu manajemen Sumber Daya Manusia (SDM) termasuk ke dalam tahapan pengembangan SDM, walaupun dalam konteks pengembangan SDM diklat hanya salah satu metode pengembangan SDM. Training atau diklat menurut Buckley and Caple (dalam Reni Suzana, 2016) diartikan sebagai suatu rencana yang sistematis untuk merubah atau mengembangkan pengetahuan, keterampilan dan perilaku melalui pembelajaran dari pengalaman guna mencapai kinerja yang efektif dari kegiatan atau tingkatan berbagai kegiatan.

Istilah pelatihan merupakan terjemahan dari kata "training" dalam bahasa Inggris. Mustofa Kamil, (2010), secara harfiah akar kata training adalah train yang berarti:1) memberi pelajaran dan praktik (give teaching and practice); 2) menjadikan berkembang dalam arah yang dikehendaki (cause to grow in a required direction); 3) persiapan (practice). Dari kedua pendapat tersebut dapat disimpulkan bahwa pelatihan merupakan usaha sadar dan terencana dalam mengembangkan aspek kognitif, afektif dan psikomotor melalui proses pembelajaran menunjang tugas dan peran pekerjaannya.

Diklat bagi ASN merupakan proses transformasi kualitas SDM aparatur negara yang menyentuh empat dimensi utama yaitu dimensi spritual, intelektual, mental dan phisikal yang terarah pada perubahanperubahan mutu dari ke-4 dimensi SDM aparatur negara. Agar terwujudnya sosok aparatur negara yang memiliki jati diri sebagai abdi negara dan pelayan masyarakat, dalam mengemban amanah perjuangan bangsa mewujudkan cita-cita dan tujuan bernegara, sesuai posisi dan peran tugas kelembagaan dalam sistem administrasi negara kesatuan Republik Indonesia (Mustopadidjaja, 2016) 
Peraturan Kepala Lembaga Administrasi Negara nomor 5 tahun 2008 tentang standar kompetensi widyaiswara bahwa seorang widyaiswara harus memiliki kompetensi pengelolaan pembelajaran, kompetensi kepribadian, kompetensi sosial dan kompetensi substantif.

Tugas utama seorang widyaiswara adalah memiliki kemampuan yang tidak dapat dipisahkan dari menguasai pengetahuan di bidangnya, keterampilan dan sikap untuk melaksanakan tugas sebagai widyaiswara yang berkemampuan yang dimilikinya untuk kebutuhan tugasnya. Widyaiswara memegang peranan sangat penting melaksanakan proses belajar mengajar. Fungsi widyaiswara yang berubah dari penguasaan tunggal di kelas menjadi pengelola proses belajar mengajar.

Kehadiran seorang widyaiswara dalam proses belajar mengajar masih tetap memegang peranan penting. Kehadiran widyaiswara dalam kegiatan pembelajaran di kelas masih tetap memegang peranan penting. Peranan widyaiswara belum dapat digantikan oleh peralatan yang sangat canggih sekalipun seperti mesin, televisi, tape recorder, ataupun komputer yang paling canggih. Widyaiswara dikatakan berkualitas apabila dapat menampilkan kelakuan yang baik dalam usahanya dalam mengajar. Jadi keberhasilan dalam proses belajar mengajar sangat ditentukan oleh kemampuan seorang widyaiswara dalam mengelola proses belajar mengajar.

Untuk menjaga kualitas penyelenggaraan kegiatan diklat, salah satu upayanya adalah cara widyaiswara dalam mengelola kelas. Pengelolaan kelas yang baik diantaranya: 1) mengizinkan kepada peserta diklat untuk mengembangkan kecakapan sendiri dan tidak tergantung pada orang lain; 2) membuat suasana yang hangat terhadap antara widyaiswara dan peserta diklat; 3) menghasilkan sikap yang positif peserta diklat terhadap kelasnya (Suryosubroto, 2002).

Kemampuan mengelola proses belajar mengajar adalah kesanggupan atau kecakapan para widyaiswara dalam menciptakan suasana komunikasi yang edukatif antara widyaiswara dan peserta diklat yang mencakup segi kognitif, efektif dan psikomotor, sebagai upaya mempelajari sesuatu berdasarkan perencanaan sampai dengan tahap evaluasi dan tindaklanjut agar tercapai tujuan pengajaran. Widyaiswara memiliki kemampuan dasar yang diperlukan sebagai fasilitator, pendidik, pembimbing dan pengajar. Kemampuan tersebut merupakan cermin dari kompetensi yang dimilikinya.

Oleh karena itu proses belajar mengajar di kelas harus dapat mengembangkan cara belajar peserta diklat untuk mendapatkan, mengelola, menggunakan dan mengkomunikasikan apa yang telah diperoleh dalam proses belajar mengajar dalam sebuah diklat. Widyaiswara adalah orang atau pihak yang berinteraksi langsung dengan peserta diklat dalam proses belajar mengajar.

$\begin{array}{ccc}\text { Widyaiswara } & \text { sangat berperan } \\ \text { dalam mengelola } & \text { kelas. } & \text { Apabila }\end{array}$ widyaiswara mampu mengelola kelasnya dengan baik, maka tidaklah sukar bagi widyaiswara untuk mencapai tujuan dan sasaran yang telah di rumuskan. Dan juga hasil diklat lebih optimal jika seorang Widyaiswara dapat menciptakan lingkungan belajar yang kondusif dan efektif.

Oleh karena itu, berkualitas tidaknya proses diklat sangat tergantung pada kreativitas dan inovasi proses belajar mengajar yang diterapkan oleh widyaiswara dalam pembelajarannya. Hal ini senada yang diungkapkan oleh Sardiman, (1990) mengemukakan bahwa peranan widyaiswara dalam kegiatan tugas dan peranan widyaiswara kegiatan proses belajar mengajar diantara sebagai informatory, organisator, motivator, pengarah/director, inisiator, transmitter, fasilitator, evaluator pembelajaran di kelas, maka peserta diklat merupakan subjek yang terlibat langsung dalam proses untuk mencapai tujuan pendidikan.

Kinerja seseorang menunjukkan tingkat kompetensi atau profesionalismenya. Kemampuan atau kompetensi tersebut dapat dianggap sebagai pilar dari suatu profesi, dimana seorang profesional harus ditopang dengan kompetensi yang kuat.

Spencer and Spencer (dalam Uno, 2008) memandang bahwa kompetensi sebagai karakteristik yang menonjol dari 
seorang individu yang berhubungan dengan kinerja efektif dan atau superior dalam suatu pekerjaan atau situasi. Dari pendapat tersebut dapat di pahami bahwa kemampuan adalah merujuk pada kinerja seseorang dalam suatu pekerjaan yang bias dilihat dari pikiran, sikap dan perilakunya.

Dalam arti khusus dapat dikatakan bahwa pada setiap diri widyaiswara itu terletak tanggung jawab untuk membawa para peserta diklat pada taraf kematangan tertentu. Dalam rangka ini widyaiswara tidak semata-mata sebagai pengajar yang transfer of knowledge, tetapi juga sebagai transfer of values. (Sardiman, 1990)

Widyaiswara sebagai tenaga professional dibidang kependidikan, disamping memahami hal-hal yang bersifat filosofis dan konseptual, harus juga mengetahui dan melaksanakan hal-hal yang bersifat teknis. Hal-hal yang bersifat teknis ini, terutama kegiatan mengelola dan melaksanakan interkasi belajar mengajar.

Widyaiswara di tuntut agar mendesain program satuan acara pembelajaran yang sesuai dengan tuntutan kurikulum dan harus banyak melakukan latihan terlebih dahulu. Dengan demikian seorang widyaiswara akan memperoleh suatu pengalaman yang sangat berharga bagi kualitas profesinya di masa yang akan datang.

\section{METODE PENELITIAN}

1. Penelitian ini bertujuan untuk mengetahui kinerja dikjartih widyaiswara pada diklat Revolusi Mental di Balai Diklat Keagamaan Palembang.

2. Jenis penelitian ini adalah menggunakan penelitian deskriptif. Hasan (2006) menyatakan penelitian deksriptif adalah penelitian yang dilakukan untuk mengetahui nilai dari suatu variabel, dalam hal ini variabel mandiri, baik satu variabel atau lebih (independent) tanpa membuat perbandingan atau menghubungkan dengan variabel lain.

3. Subjek penelitian ini adalah seluruh peserta diklat Revolusi Mental angkatan ke-2 yang berasal dari perwakilan kanwil Provinsi Sumatera Selatan, perwakilan kanwil Provinsi
Lampung, Perwakilan kanwil Provinsi Bengkulu dan Perwakilan kanwil Provinsi Bangka Belitung.

4. Waktu pengambilan data ketika peserta diklat mengikuti tatap muka diklat revolusi mental angkatan ke-2 yang dimulai dari tanggal 5 April sampai 10 April 221.

5. Teknik pengumpulan data pada penelitian ini menggunakan kuesioner. Kuesioner dalam penelitian ini menggunakan kuesioner dimana seluruh isi pernyataan di dalam kuesioner ini diambil dari kuesioner penilaian kinerja guru yang di terbitkan oleh Kementerian Pendidikan dan Kebudayaan tahun 2016.

Peneliti tidak mengembangkan kuesioner untuk menilai kinerja widyaiswara, tetapi mengadopsi dari penilaian kinerja guru. Penulis memberikan alasan bahwa penilaian yang diadopsi dari penilaian kinerja guru lebih mudah digunakan dan terukur dalam menilai. Kuesioner ini ada komponen untuk menilai kinerja widyaiswara diantaranya menguasai materi diklat dilengkapi 6 indikator serta ada komponen kemahiran mengajar dilengkapi 14 indikatornya.

Kuesioner ini terdiri dari komponen pernyataan menguasai materi yang terdiri atas 6 indikator dilengkapi dengan jawaban Tidak Pernah (TP), Kadang-kadang (KD) dan Sering (SR). Dalam analisis kuantitatif, penulis menggunakan Skala Likert. Untuk yang menjawab Tidak Pernah (TP) diberi skor 0, Kadang-kadang (KD) diberi skor 1 serta Sering (SR) diberi skor 2. Untuk komponen pernyataan kemahiran mengajar terdiri atas 14 indikator pernyataan dan setiap yang menjawab tidak pernah (TP) diberi skor 0 , Kadang-kadang (KD) diberi skor 1 , serta sering (SR) diberi skor 2 dari pernyataan.

Untuk komponen pernyataan menguasai materi terdiri atas 6 indikator pernyataan yaitu 1) widyaiswara menyampaikan materi diklat dengan contoh dalam kehidupan sehari-hari; 2) widyaiswara menjelaskan materi diklat dari buku 
paket dan sumber belajar lainnya; 3) widyaiswara memberikan contoh atau permasalahan yang berhubungan dengan keadaan saat ini; 4) widyaiswara menjawab pertanyaan dengan jelas; 5) widyaiswara menjawab pertanyaan dengan benar; 6) widyaiswara mengajar sesuai dengan materi diklat. Untuk komponen kemahiran mengajar terdiri atas 14 indikator pernyataan yaitu 1) widyaiswara menyampaikan kegiatan yang akan dilakukan selama pembelajaran; 2) widyaiswara memberikan motivasi kepada saya dan teman teman; 3) widyaiswara menyampaikan materi diklat dengan mudah dimengerti; 4) widyaiswara mengajar dengan cara yang bervariasi misalnya diskusi, demontrasi, tanya jawab, ceramah, dll; 5)widyaiswara berbicara dengan jelas ketika menyampaikan materi diklat; 6) widyaiswara meminta belajar secara berkelompok; 7) widyaiswara mengajar dengan cara yang menyenangkan dan menarik; 8) widyaiswara terampil menggunakan alat bantu saat mengajar; 9) widyaiswara membimbing saya dan teman teman ketika mengalami kesulitan;10) widyaiswara membuat suasana nyaman saat melaksanakan proses belajar mengajar; 11) widyaiswara memberi kesempatan kepada saya dan teman-teman untuk bertanya atau menjawab; 12) widyaiswara menghargai kemampuan saya dan teman-teman; 13) widyaiswara memberitahukan nilai hasil belajar;1 4) widyaiswara memberikan tugas dalam pembelajaran (Kemendikbud, 2016)

Widyaiswara yang mengajar materi mata diklat kelompok inti diklat Revolusi Mental dinilai oleh peserta yang mengikuti diklat Revolusi Mental angkatan ke-2. Peserta memberikan penilaian kepada widyaiswara yang mengajar di Revolusi Mental. Penilaian dilaksanakan setelah proses belajar mengajar yang dilakukan oleh widyaiswara berakhir. Peserta diklat memberikan penilaian dengan cara memberikan jawaban tidak pernah
(TP), kadang-kadang (KD) dan sering (SR) pada setiap indikator/pernyataan. Kriteria penilaian kinerja widyaiswara untuk dikjartih dengan kualifikasi dapat dilihat pada tabel 2 .

Tabel 2 kriteria penilaian dikjartih

\begin{tabular}{|l|c|}
\hline $\begin{array}{c}\text { Sangat } \\
\text { memuaskan }\end{array}$ & $90,00 \leq$ skor $\leq 100$ \\
\hline \multicolumn{1}{|c|}{ Memuaskan } & $80 \leq$ skor $\leq 90,00$ \\
\hline $\begin{array}{l}\text { Cukup } \\
\text { Memuaskan }\end{array}$ & $70,00 \leq$ skor $\leq 80,00$ \\
\hline Tidak memuaskan & skor $\leq 70,00$ \\
\hline
\end{tabular}

Diklat

Sumber: Sk Ka Badan Litbang dan

Nilai dari komponen pelaksanaan proses belajar mengajar dapat dihitung menggunakan rumus:

$$
\mathrm{N}=\frac{\text { jumlah jawaban responden }}{\text { jumlah } \text { responden }} \times 100
$$

Dengan menggunakan skala likert maka variabel yang akan di ukur dijabarkan menjadi indikator variabel. Untuk keperluan analisis kuantitatif maka jawaban pada lembar kuesioner dapat diberi skor untuk yang menjawab tidak pernah (TP) diberi skor 0 , untuk yang menjawab kadang-kadang (KD) diberi skor 1, dan untuk yang menjawab sering (SR) diberi skor 2 .

6. Pengolahan data adalah suatu proses dalam memperoleh data ringkasan atau angka ringkasan dengan menggunakan cara-cara atau rumus-rumus tertentu (Hasan, 2006). Sesuai tujuan penelitian yang ditetapkan maka untuk pengolahan data menggunakan tabel biasa (main table). Menurut Hasan (2006) tabel biasa adalah tabel yang yang disusun berdasarkan sifat responden tertentu dan tujuan tertentu. Tabel biasa sifatnya kolektif dan memuat beberapa jenis informasi. Data yang sudah diperoleh dan diolah serta disajikan agar mudah dibaca dan dimengerti orang lain atau pengambil keputusan, perlu ditampilkan ke dalam bentuk bentuk tertentu. Penampilan data yang sudah di olah disajikan dalam 
bentuk tabel data dan grafik batang atau balok.

\section{TEMUAN DAN PEMBAHASAN}

\section{Temuan}

Hasil kinerja dikjartih widyaiswara dinilai menggunakan kuesioner. Kuesioner ini bertujuan untuk menghimpun data atau informasi kinerja widyaiswara dari peserta diklat. Kuesioner ini diberikan kepada 30 orang peserta diklat angkatan ke-2 dan digunakan untuk menilai kinerja widyaiswara dalam kegiatan Dikjartih.

Materi mata diklat yang diajarkan oleh Abu Bakar selaku widyaiswara adalah konsep dasar pemimpin berkarakter. Materi ini berdurasi 3 jam diklat dilaksanakan pada hari selasa tanggal 6 April 2021. Proses proses belajar mengajar dimulai dari pukul 07.30 WIB sampai pukul 09.45 WIB, dimana 1 jam diklat setara 45 menit. Setelah widyaiswara Abu Bakar selesai melakukan kegiatan proses belajar mengajar, penulis melalui panitia penyelenggara diklat Revolusi Mental angkatan ke-2 membagikan intrumen penilaian berupa kuesioner kepada peserta diklat.

Dari hasil pengumpulan data melalui kuesioner untuk komponen menguasai materi yang terdiri atas 6 indikator pernyataan dan komponen kemahiran mengajar terdiri atas 14 indikator pernyataan. Materi konsep dasar pemimpim berkarakter dapat dibaca pada tabel 3 dan 4 sebagai berikut.

Tabel 3 penilaian kinerja dikjartih untuk menguasai materi

\begin{tabular}{|c|c|c|c|}
\hline \multirow[t]{2}{*}{ Pernyataan } & $\mathrm{TP}$ & $\mathrm{KD}$ & SR \\
\hline & 0 & 1 & 2 \\
\hline 1 & 2 & 3 & 4 \\
\hline $\begin{array}{l}\text { 1. Widyaiswara } \\
\text { menyampaikan materi } \\
\text { diklat dengan contoh } \\
\text { dalam kehidupan } \\
\text { sehari-hari }\end{array}$ & 1 & 2 & 27 \\
\hline $\begin{array}{ll}\text { 2. } & \text { widyaiswara } \\
\text { menjelaskan materi } \\
\text { diklat dari buku paket }\end{array}$ & 2 & 8 & 20 \\
\hline
\end{tabular}

\begin{tabular}{|c|c|c|c|c|}
\hline & $\begin{array}{l}\text { dan sumber belajar } \\
\text { lainnya }\end{array}$ & & & \\
\hline 3. & $\begin{array}{l}\text { widyaiswara } \\
\text { memberikan contoh } \\
\text { atau permasalahan yang } \\
\text { berhubungan dengan } \\
\text { keadaan saat ini }\end{array}$ & - & 3 & 27 \\
\hline 4. & $\begin{array}{l}\text { widyaiswara menjawab } \\
\text { pertanyaan dengan jelas }\end{array}$ & - & 4 & 26 \\
\hline 5. & $\begin{array}{l}\text { widyaiswara menjawab } \\
\text { pertanyaan dengan } \\
\text { benar }\end{array}$ & 1 & 3 & 26 \\
\hline 6. & $\begin{array}{l}\text { widyaiswara mengajar } \\
\text { sesuai dengan materi } \\
\text { diklat }\end{array}$ & - & 1 & 29 \\
\hline
\end{tabular}

Tabel 4 penilaian kinerja dikjartih kemahiran

mengajar mata diklat konsep dasar pemimpin berkarakter

\begin{tabular}{|c|c|c|c|}
\hline \multirow[t]{2}{*}{ Pernyataan } & TP & KD & SR \\
\hline & 0 & 1 & 2 \\
\hline 1 & 2 & 3 & 4 \\
\hline $\begin{array}{ll}\text { 1. } & \text { Widyaiswara } \\
\text { menyampaikan kegiatan } \\
\text { yang akan dilakukan } \\
\text { selama proses belajar } \\
\text { mengajar }\end{array}$ & - & 4 & 26 \\
\hline $\begin{array}{l}\text { 2. Widyaiswara } \\
\text { memberikan motivasi } \\
\text { kepada saya dan teman } \\
\text { teman }\end{array}$ & 1 & 3 & 26 \\
\hline $\begin{array}{ll}\text { 3. } & \text { Widyaiswara } \\
\text { menyampaikan materi } \\
\text { diklat dengan mudah } \\
\text { dimengerti }\end{array}$ & & 2 & 28 \\
\hline $\begin{array}{l}\text { 4. Widyaiswara mengajar } \\
\text { dengan cara yang } \\
\text { bervariasi misalnya } \\
\text { diskusi, demontrasi, } \\
\text { tanya jawab, cermah,dll }\end{array}$ & & 2 & 28 \\
\hline $\begin{array}{ll}\text { 5. } & \text { Widyaiswara berbicara } \\
\text { dengan jelas ketika } \\
\text { menyampaikan materi } \\
\text { diklat }\end{array}$ & & 3 & 27 \\
\hline $\begin{array}{llr}\text { 6. } & \begin{array}{l}\text { Widyaiswara } \\
\text { belajar }\end{array} & \text { meminta } \\
\text { berkelompok. } & \text { secara } \\
\end{array}$ & 2 & 3 & 25 \\
\hline $\begin{array}{llr}\text { 7. } & \text { widyaiswara mengajar } \\
\text { dengan cara yang } \\
\text { menyenangkan dan } \\
\text { menarik. }\end{array}$ & & 6 & 24 \\
\hline $\begin{array}{l}\text { 8. widyaiswara terampil } \\
\text { menggunakan alat } \\
\text { bantu saat mengajar }\end{array}$ & & 4 & 26 \\
\hline $\begin{array}{l}\text { 9. Widyaiswara } \\
\text { membimbing saya dan } \\
\text { teman-teman ketika } \\
\text { mengalami kesulitan }\end{array}$ & 1 & 3 & 26 \\
\hline 10. Widyaiswara membuat & 1 & 5 & 24 \\
\hline
\end{tabular}




\begin{tabular}{|l|l|l|l|}
\hline $\begin{array}{l}\text { suasana nyaman saat } \\
\text { melaksanakan proses } \\
\text { belajar mengajar }\end{array}$ & & & \\
\hline 11. $\begin{array}{l}\text { Widyaiswara } \\
\text { memberikan kepada } \\
\text { kesempatan } \\
\text { saya dan teman teman } \\
\text { untuk bertanya atau } \\
\text { menjawab }\end{array}$ & 1 & 1 & 28 \\
\hline 12. $\begin{array}{l}\text { Widyaiswara } \\
\text { menghargai } \\
\text { kemampuan saya dan } \\
\text { teman teman }\end{array}$ & 1 & 3 & 26 \\
\hline 13. $\begin{array}{l}\text { Widyaiswara } \\
\text { memberitahukan nilai } \\
\text { hasil belajar }\end{array}$ & 5 & 10 & 15 \\
\hline 14. $\begin{array}{l}\text { Widyaiswara tugas } \\
\text { memberikan } \\
\text { dalam proses belajar } \\
\text { mengajar. }\end{array}$ & 2 & 3 & 25 \\
\hline
\end{tabular}

Keterangan:

a. Peserta memberikan jawaban dengan jujur atas pernyataan pada kolom (1) dengan memberi tanda centang $(\sqrt{ })$ pada:

b. Kolom (2), tidak pernah (TP), skor 0

c. Kolom (3), kadang-kadang (KD), skor 1

d. Kolom (4), sering (SR), skor 2.

e. Angka 1, 2, 27 menunjukkan banyaknya peserta yang memberikan penilaian (jawaban)

Selanjutnya widyaiswara Mardiansyah pada jadwal yang telah dikeluarkan oleh panitia diklat mengajarkan 4 materi mata diklat diantaranya: 1) Proses terbentuknya pemimpin berkarakter berdurasi 6 jam pelatihan; 2) Strategi membangun pemimpin berkarakter berbasis nilai-nilai agama berdurasi 9 jam diklat; 3) Internalisasi nilai-nilai agama dalam membentuk pemimpin berkarakter berdurasi 11 jam diklat dan 4) Personal Goal Setting berdurasi 7 (tujuh) jam diklat.

Proses belajar mengajar dimulai dari materi mata diklat Proses terbentuknya pemimpin berkarakter berdurasi 6 jam diklat dilaksanakan pada tanggal 6 April 2021 dimulai pukul 10.00 WIB sampai pukul 15.15 WIB diselingi waktu istirahat. Setelah selesai melaksanakan proses belajar mengajar, peserta diminta untuk menilai widyaiswara dengan menggunakan intrumen kuesioner yang telah diberikan.
Berikutnya Mardiansyah melaksanakan proses belajar mengajar pada hari Selasa, 6 April 2021 dimulai dari pukul 15.30 WIB sampai pukul 17.00 WIB dan dilanjutkan pada hari Rabu, 7 April 2021 dimulai dari pukul 07.30 WIB sampai pukul 12.15 WIB dengan materi mata diklat Strategi membangun pemimpin berkarakter berbasis nilai-nilai agama berdurasi 9 (sembilan) jam diklat. Setelah itu, dilanjutkan mengajar mata diklat Internalisasi nilainilai agama dalam membentuk pemimpin berkarakter berdurasi 11 jam diklat. Materi mata diklat ini dilaksanakan hari Rabu, 7 April 2021 dimulai dari Pukul 13.00 WIB sampai pukul 17.00 WIB dan dilanjutkan ke hari Kamis, 8 April 2021, dimulai dari pukul 07.30 WIB sampai pukul 11.30 WIB. Berikutnya Mardiansyah melaksanakan proses belajar mengajar dengan materi mata diklat Personal Goal Setting berdurasi 7 jam pelatihan pada hari Jumat, 9 April 2021 dimulai pukul 07.30 WIB sampai pukul 14.15 WIB diselingi waktu istirahat.

Setelah melakukan serangkaian proses belajar mengajar dimulai dari hari selasa, 5 April 2021 sampai hari Jum' at, 9 April 2021, penulis melalui panitia penyelenggara diklat Revolusi Mental, peserta diminta untuk menilai widyaiswara dengan menggunakan intrumen kuesioner yang telah diberikan.

Widyaiswara yang mengajar materi inti pada diklat Revolusi Mental angkatan ke-2 berjumlah 2 orang, dimana 1 orang hanya mengajarkan 1 mata diklat berdurasi 3 jam diklat dan 1 orang lagi mengajarkan 4 mata diklat berdurasi 33 jam diklat yang terdiri dari 6, 9, 11 dan 7 jam diklat. Untuk mencapai keseimbangan jumlah jam diklat, maka penulis mengambil mata diklat dengan jumlah durasi sama dengan widyaiswara mengajarkan 1 mata diklat yaitu Proses terbentuknya pemimpin berkarakter.

Dari hasil pengumpulan data melalui intrumen kuesioner yang telah disebar ke peserta diklat, maka untuk mata diklat proses terbentuknya pemimpin berkarakter diampu oleh widyaiswara Mardiansyah, datanya dapat dibaca pada tabel 5 dan 6 sebagai berikut:

Tabel 5 penilaian kinerja dikjartih untuk 
menguasai materi mata diklat proses terbentuknya pemimpin berkarakter

\begin{tabular}{|c|c|c|c|}
\hline \multirow[t]{2}{*}{ Pernyataan } & $\mathrm{TP}$ & KD & SR \\
\hline & 0 & 1 & 2 \\
\hline 1 & 2 & 3 & 4 \\
\hline $\begin{array}{l}\text { 1. Widyaiswaramenyamp } \\
\text { aikan materi diklat } \\
\text { dengan contoh dalam } \\
\text { kehidupan sehari-hari }\end{array}$ & & 1 & 29 \\
\hline 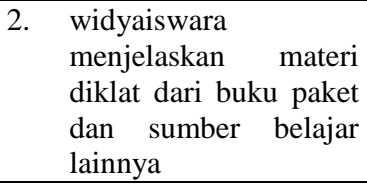 & 1 & 9 & 20 \\
\hline $\begin{array}{l}\text { 3. } \\
\text { widyaiswara } \\
\text { memberikan contoh } \\
\text { atau permasalahan } \\
\text { yang berhubungan } \\
\text { dengan keadaan saat } \\
\text { ini }\end{array}$ & 1 & 1 & 28 \\
\hline $\begin{array}{ll}\text { 4. } & \text { widyaiswara } \\
\text { menjawab pertanyaan } \\
\text { dengan jelas }\end{array}$ & - & 4 & 26 \\
\hline $\begin{array}{l}\text { 5. } \\
\text { midyaiswara } \\
\text { menjawab pertanyaan } \\
\text { dengan benar }\end{array}$ & - & 1 & 29 \\
\hline $\begin{array}{l}\text { 6. } \begin{array}{l}\text { widyaiswara mengajar } \\
\text { sesuai dengan materi } \\
\text { diklat }\end{array} \\
\end{array}$ & - & 1 & 29 \\
\hline
\end{tabular}

Tabel 6 Penilaian kinerja dikjartih untuk kemahiran mengajar mata diklat proses terbentuknya pemimpin berkarakter

\begin{tabular}{|c|c|c|c|}
\hline \multirow[t]{2}{*}{ Pernyataan } & $\mathrm{TP}$ & KD & SR \\
\hline & 0 & 1 & 2 \\
\hline 1 & 2 & 3 & 4 \\
\hline $\begin{array}{l}\text { 1. } \\
\text { widyaiswara } \\
\text { menyampaikan kegiatan } \\
\text { yang akan dilakukan } \\
\text { selama proses belajar } \\
\text { mengajar }\end{array}$ & - & 5 & 25 \\
\hline $\begin{array}{l}\text { 2. } \\
\text { midyaiswara } \\
\text { memberikan motivasi } \\
\text { kepada saya dan teman } \\
\text { teman }\end{array}$ & - & 4 & 26 \\
\hline $\begin{array}{ll}\text { 3. } & \text { widyaiswara } \\
\text { menyampaikan materi } \\
\text { diklat dengan mudah } \\
\text { dimengerti }\end{array}$ & - & 2 & 28 \\
\hline 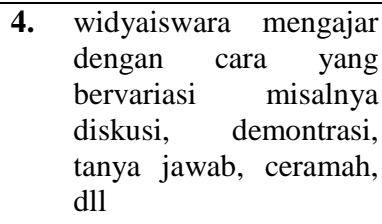 & - & 3 & 27 \\
\hline $\begin{array}{llr}\text { 5. } & \text { widyaiswara } & \text { berbicara } \\
\text { dengan jelas } & \text { ketika } \\
\text { menyampaikan } & \text { materi }\end{array}$ & - & 2 & 28 \\
\hline
\end{tabular}

\begin{tabular}{|c|c|c|c|c|}
\hline & diklat & & & \\
\hline & $\begin{array}{l}\text { widyaiswara meminta } \\
\text { belajar secara } \\
\text { berkelompok }\end{array}$ & 5 & 11 & 14 \\
\hline 7. & $\begin{array}{lr}\text { widyaiswara mengajar } \\
\text { dengan cara yang } \\
\text { menyenangkan } \\
\text { menarik }\end{array}$ & - & 1 & 29 \\
\hline & $\begin{array}{l}\text { widyaiswara terampil } \\
\text { menggunakan alat } \\
\text { bantu saat mengajar }\end{array}$ & - & 4 & 26 \\
\hline 9. & $\begin{array}{l}\text { widyaiswara } \\
\text { membimbing saya dan } \\
\text { teman teman ketika } \\
\text { mengalami kesulitan }\end{array}$ & 1 & 5 & 24 \\
\hline 10. & $\begin{array}{l}\text { widyaiswara membuat } \\
\text { suasana nyaman saat } \\
\text { melaksanakan proses } \\
\text { belajar mengajar }\end{array}$ & - & 2 & 28 \\
\hline 11. & $\begin{array}{l}\text { widyaiswara memberi } \\
\text { kesempatan kepada } \\
\text { saya dan teman-teman } \\
\text { untuk bertanya atau } \\
\text { menjawab }\end{array}$ & - & 2 & 28 \\
\hline 12. & $\begin{array}{l}\text { widyaiswara } \\
\text { menghargai } \\
\text { kemampuan saya dan } \\
\text { teman-teman }\end{array}$ & - & 2 & 28 \\
\hline 13. & $\begin{array}{l}\text { widyaiswara } \\
\text { memberitahukan nilai } \\
\text { hasil belajar }\end{array}$ & 4 & 7 & 19 \\
\hline 14. & $\begin{array}{l}\text { widyaiswara } \\
\text { memberikan tugas } \\
\text { dalam proses belajar } \\
\text { mengajar. }\end{array}$ & 2 & 10 & 18 \\
\hline
\end{tabular}

\section{Pembahasan}

Berdasarkan data hasil penilaian dikjartih yang dilakukan oleh peserta diklat untuk komponen menguasai materi dan kemahiran mengajar pada mata diklat konsep dasar pemimpin berkarakter dengan widyaiswara Abu Bakar. Hasil penilaian sebagai berikut:

a. Untuk komponen menguasai materi

Tabel 7 jawaban peserta untuk mata diklat konsep dasar pemimpin berkarakter

\begin{tabular}{|c|c|}
\hline Penilaian (jawaban) & $\sum$ jawaban \\
\hline Tidak Pernah (TP) & 4 \\
\hline Kadang kadang (KD) & 21 \\
\hline Sering (SR) & 155 \\
\hline Jumlah & 180 \\
\hline
\end{tabular}

Berdasarkan data peserta yang memberikan jawaban tidak pernah (TP) sebanyak 4 sehingga menghasilkan nilai. 


$$
\frac{4}{180} x 100=2,2
$$

Peserta diklat yang memberikan jawaban kadang-kadang (KD) sebanyak 21 sehingga diperoleh nilai

$$
\frac{21}{180} x 100=11,66
$$

Peserta yang memilih jawaban sering (SR) sebanyak 155, nilai yang diperoleh sebesar:

$$
\frac{155}{180} \times 100=86,11
$$

Jadi, untuk menguasai materi peserta memberikan nilai 86,11 dalam kategori memuaskan.

b. Untuk komponen kemahiran mengajar

Tabel 8 jawaban peserta diklat untuk mata

diklat konsep dasar pemimpin berkarakter

\begin{tabular}{|c|c|}
\hline Penilaian & $\sum$ jawaban \\
\hline $\begin{array}{c}\text { Tidak Pernah } \\
\text { (TP) }\end{array}$ & 14 \\
\hline $\begin{array}{c}\text { Kadang Kadang } \\
\text { (KD) }\end{array}$ & 52 \\
\hline Sering (SR) & 350 \\
\hline jumlah & 420 \\
\hline
\end{tabular}

Peserta memberikan nilai jawaban tidak pernah sebanyak 14 , maka diberikan nilai sebesar

$$
\frac{14}{420} \times 100=3,33
$$

Kategori memberikan jawaban kadangkadang sebanyak 52 sehingga nilai yang diberikan sebesar

$$
\frac{52}{420} \times 100=12,38
$$

Hasil penilaian kemahiran mengajar untuk mata diklat konsep dasar pemimpin berkarakter yang diampu widyaiswara Abu Bakar datanya sebagai berikut

$$
\frac{350}{420} \times 100=83,33
$$

Berdasarkan data yang diperoleh dari 30 peserta diklat maka komponen menguasai materi mendapatkan nilai 86,11 (memuaskan) dan komponen kemahiran mengajar mendapatkan nilai 83,33 (memuaskan).

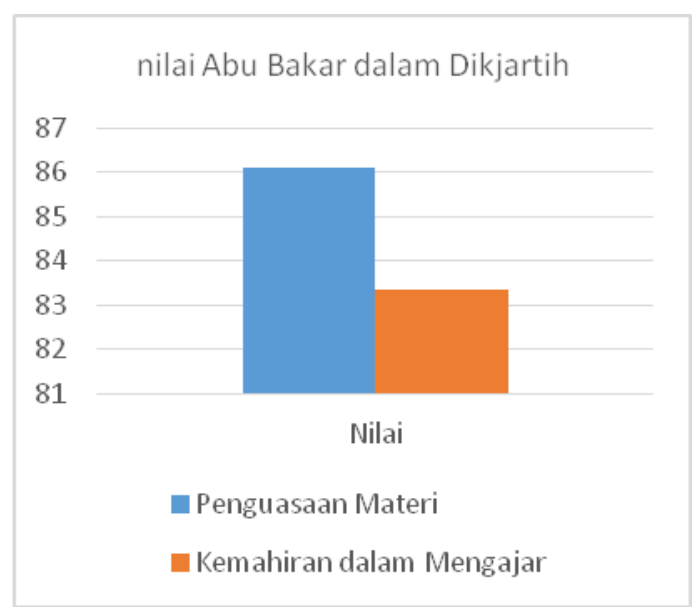

Gambar 1 grafik hasil penilaian dikjartih

widyaiswara Abu Bakar komponen menguasai materi dan kemahiran mengajar.

Penilaian kinerja dikjartih untuk mata diklat 'Proses terbentuknya pemimpin berkarakter' diampu oleh Mardiansyah

a. komponen menguasai materi dapat dibaca pada tabel 9

Tabel 9 jawaban peserta diklat pada mata diklat

proses terbentuknya pemimpin

berkarakter

\begin{tabular}{|c|c|}
\hline Penilaian & $\sum$ jawaban \\
\hline Tidak pernah (TP) & 2 \\
\hline Kadang-Kadang (KD) & 17 \\
\hline Sering (SR) & 161 \\
\hline Jumlah & 180 \\
\hline
\end{tabular}

Berdasarkan data peserta yang memberikan jawaban tidak pernah (TP) sebanyak 2 sehingga nilai yang diberikan

$$
\frac{2}{180} x 100=1,11
$$


Peserta diklat yang memberikan jawaban kadang-kadang (KD) sebanyak 21 sehingga nilai yang diberikan

$\frac{17}{180} \times 100=9,44$

Peserta yang memberikan jawaban sering (SR) sebanyak 161, sehingga nilai yang diberikan

$$
\frac{161}{180} \times 100=89,44
$$

Komponen menguasai materi peserta memberikan nilai 89,44 dalam kategori memuaskan.

b. Komponen kemahiran mengajar

Tabel 10 jawaban peserta diklat untuk mata diklat proses terbentuknya pemimpin berkarakter.

\begin{tabular}{|c|c|}
\hline Penilaian & $\sum$ jawaban \\
\hline Tidak pernah (TP) & 12 \\
\hline Kadang-Kadang (KD) & 60 \\
\hline Sering (SR) & 348 \\
\hline jumlah & 420 \\
\hline
\end{tabular}

Berdasarkan data peserta yang memilih jawaban tidak pernah (TP) sebanyak 12, nilai yang diberikan

$$
\frac{12}{420} x 100=2,85
$$

Kategori memberikan jawaban kadangkadang (KD) sebanyak 60, maka nilai kemahiran dalam mengajar

$\frac{60}{420} \times 100=14,28$

Peserta yang memberikan jawaban sering (SR) sebanyak 348, sehingga nilai yang diberikan

$$
\frac{348}{420} \times 100=82,85
$$

Hasil yang diberikan oleh peserta diklat kepada widyaiswara Mardiansyah sebesar 82,85 (memuaskan).

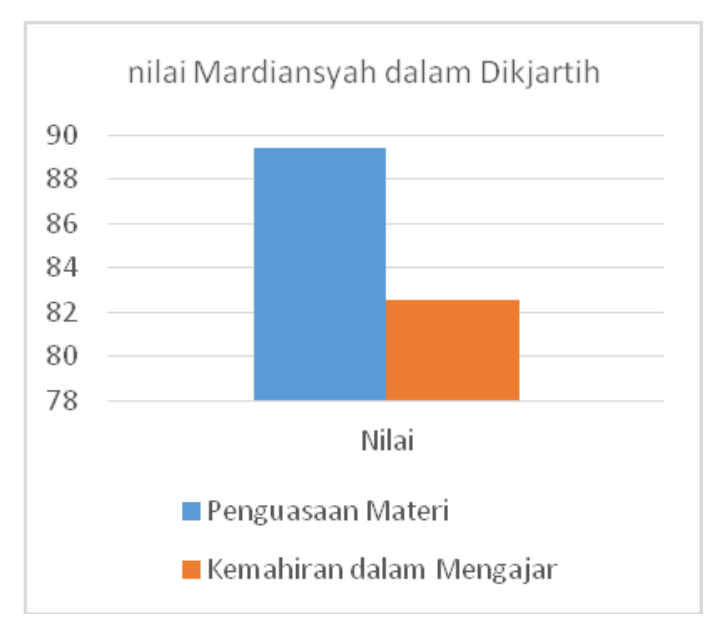

Gambar 2 Grafik penilaian dikjartih mardiansyah komponen menguasai materi dan kemahiran mengajar

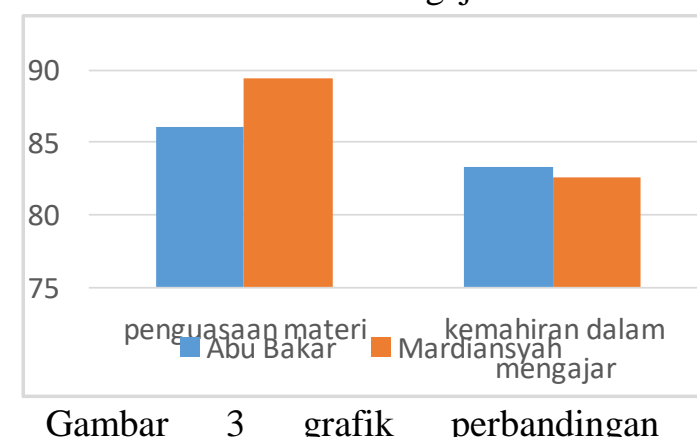
penilaian

dan

dikjartih antara Abu Bakar

$$
\text { Mardiansyah }
$$

Menguasai materi adalah kemampuan yang harus dimiliki oleh seorang widyaiswara dikarenakan bagian yang tak terpisahkan dari proses belajar mengajar. Oleh karena itu kemampuan menguasai materi diklat jangan dianggap pelengkap bagi profesi widyaiswara. Widyaiswara yang bertaraf profesional penuh mutlak harus menguasai materi yang akan diajarkannya.

Menguasai materi diklat dan kemahiran mengajar ternyata memberikan pengaruh terhadap hasil belajar peserta diklat. Tugas dan tanggungjawab seorang widyaiswara adalah mengelola pengajaran dengan lebih efektif, dinamis, efisien, dan positif yang ditandai dengan adanya kesadaran dan keterlibatan aktif di antara dua subjek pengajaran, widyaiswara sebagai inisiatif awal dan pengarah serta pembimbing, 
sedangkan peserta diklat sebagai yang mengalami dan terlibat aktif untuk memperoleh perubahan diri dalam pengajaran.

\section{PENUTUP}

\section{Simpulan}

Dari hasil penilaian peserta diklat Revolusi Mental angkatan ke-2 terhadap widyaiswara untuk komponen penguasaan materi dan komponen kemahiran mengajar didapatkan bahwa Widyaiswara Abu Bakar mendapatkan nilai sebesar 86,11 (memuaskan) dan 83,33 (memuaskan) untuk mengajar mata diklat konsep dasar pemimpin berkarakter. Widyaiswara Mardiansyah untuk komponen penguasaan materi mendapatkan nilai 89,44 (memuaskan) dan komponen kemahiran mengajar mendapatkan nilai 82,85 (memuaskan) untuk mengajar mata diklat proses terbentuknya pemimpin berkarakter dengan kategori memuaskan. Dengan demikian penilaian kinerja dikjartih widyaiswara pada diklat Revolusi Mental di Balai Diklat Keagamaan Palembang memuaskan.

\section{Rekomendasi}

Dari hasil penelitian, penulis mengajukan beberapa rekomendasi diantaranya adalah

1) Widyaiswara yang bernama Mardiansyah perlu meningkatkan kemahiran mengajar.

2) Widyaiswara yang bernama Abu Bakar perlu meningkatkan menguasai materi dan kemahiran dalam menengajar.

3) Dalam melaksanakan dikjartih sebaiknya setiap widyaiswara mengampu sebanyak-banyak 2 mata diklat. 


\section{DAFTAR PUSTAKA}

Ali, Muhammad. 1987. Guru Dalam Proses Belajar Mengajar. Bandung: Sinar Baru Algensindo.

Atmodiwirio, Soebagio. 1993. Manajemen Training Pedoman Praktis Bagi Penyelenggara Training. Jakarta: Balai Pustaka.

Darsono Tjokrosujoso. 1995. Modul Materi Pokok Dasar-Dasar Penelitian. Jakarta. Depdikbud Direktorat Jenderal Pendidikan Dasar dan Menengah

Hasan, Iqbal. Analisis Data Penelitian dengan Statistik. Jakarta: Penerbit Bumi Aksara.

Keputusan Kepala Badan Penelitian dan Pengembangan dan Pendidikan dan Pelatihan Kementerian Agama Republik Indonesia Nomor 685 tahun 2018 tentang Petunjuk Teknis Penyelenggaraan Diklat Tenaga Teknis Pendidikan dan Keagamaan.

Keputusan Kepala Lembaga Administrasi Negara nomor 358/K.1/PDP.07/2019 tentang Pedoman Penyelenggaraan Pelatihan Revolusi Mental Untuk Pelayanan Publik.

Kemendikbud.2016. Pedoman Pengelolaan Penilaian Kinerja Guru. Kementerian Pendidikan dan Kebudayaan Jakarta. Direktorat Jenderal Guru dan Tenaga Kependidikan.

Mustopadidjaja. 2016. Modul diklat Kebijakan serta Sistem Penyelenggaraan Diklat PNS. Jakarta. Lembaga Administrasi Negara.

Mustofa Kamil.2010. Model Pendidikan dan Pelatihan "Konsep dan Aplikasi”. Alfabeta. Bandung

Peraturan Menteri Pendayagunaan Apatur Negara dan Reformasi Birokrasi nomor 22 tahun 2014 tentang Jabatan Fungsional Widyaiswara dan Angka Kreditnya.

Reni Suzana. 2016. Modul Diklat Kewidyaiswaraan Berjenjang Tingkat Tinggi Evaluasi Sistem Diklat. Jakarta. Lembaga Administrasi Negara.

Rohani, Ahmad. 2004. Pengelolaan Pengajaran. Jakarta. PT Rineka Cipta.

Sardiman, A.M. 1990. Interaksi dan Motivasi Belajar Mengajar. Jakarta: CV Rajawali.

Sudjana,Nana. 2004. Dasar-Dasar Proses Belajar Mengajar . Bandung: Sinar Baru Algensindo Offset.

Sugiyono. 2006. Metode Penelitian Kuantitatif, Kualitatif Dan $R \&$ D. Bandung. Penerbit Alfabeta.

Suryosubroto,B. 2002.Proses Belajar Mengajar Di Sekolah. Jakarta: PT Rineka Cipta.

Uno, B.Hamzah. 2008. Model Pembelajaran “Menciptakan Proses Belajar Mengajar yang Kreatif dan Efektif”. Jakarta: Bumi Aksara. 